\title{
LAYOUT PLAN ANALYSIS ON URBAN PATHWAYS, NODES AND EDGES IN KUALA MUDA FISHING VILLAGE
}

\author{
Nur Raihan Fathini Zairudin ${ }^{1}$, Ahmad Sanusi Hassan ${ }^{1 *}$, Yasser Arab ${ }^{1}$, Boonsap Witchayangkoon², Khiensak Seangklieng ${ }^{2}$ \\ ${ }^{1}$ School of Housing, Building and Planning, Universiti Sains Malaysia, Penang, Malaysia - sanusi@usm.my \\ ${ }^{2}$ Department of Civil Engineering, Thammasat School of Engineering, Thammasat University, Thailand
}

KEY WORDS: Traditional settlement, mental mapping, urban design elements, space syntax, permeability analysis, wayfinding

\begin{abstract}
:
This paper studies three urban design elements, namely pathways, nodes, and edges, in Kampung Kuala Muda, Penaga, a traditional fishing village in Penang. The case study portrays the resistance of a fishing settlement by exhibiting a unique local culture of whispering auction market that is celebrated by many, including locals and tourists. The study of the paths, edges, and nodes of the case study is carried out by applying a qualitative method and data collection through a site visit, informal interviews, and literature reviews from published journals, online news, and articles. The fishing activities heavily influence the layout setting of Kampung Kuala Muda. The urban design element is observed to be the most significant in directing the users' perspectives.
\end{abstract}

\section{INTRODUCTION}

\subsection{General Instructions}

Urban design is essential in shaping cities and towns as well as streets, buildings, and spaces. Lynch (1960) identifies five urban design elements, namely paths, edges, districts, nodes, and landmarks. Therefore, this paper will analyze the urban design elements through a case study of Kampung Kuala Muda (also known as Kuala Muda Village). The word ' Kampung' in the Malay language means 'Village' in English.

Kuala Muda Village covers an area of $222,000 \mathrm{~m}^{2}$, is one of the early settlements along the Sungai Muda River that borders Penang and Kedah. Currently, the village is well-known for its agro-tourism attraction, the Kuala Muda Whispering Market, where sellers and buyers engage in price bidding to buy and sell the fisheries products. This culture, which has been embedded among the locals and essentially becomes an attraction for the visitors and tourists, contributes significantly to the local economy (Rahmathulah, 2016).

Interestingly, the culture of the whispering market exists in both villages along the Muda River, Kampung Kuala Muda, Penaga, and Kota Kuala Muda, Kedah, although being separated by the river itself borders Penang and Kedah. According to Mas'ad (2018), the whispering auction culture in Kuala Muda was reintroduced by the local fishermen consequent the tsunami event in 2004 .

Fishing villages, referred to as traditional villages, are categorized according to their geographical locations, the Eastern Coast and Western Coast of Malaysia (Hassan, 2010). Kampung Kuala Muda is located along the Western Coast of Malaysia and exhibits the traditional patterns of an inland water village. This study aims to identify the urban design elements of Kampung Kuala Muda in Penaga regarding the mental mapping of paths, edges, and nodes.

\section{LITERATURE REVIEW}

\subsection{Background of Case Study: Kampung Kuala Muda, Penaga}

Kuala Muda lies in the Air Tawar Bay - Kuala Muda (TATKM) Coast, an internationally recognized Important Bird Area (IBA) consisting of mangrove and mudflats. The area included in the East Asian-Australasian Flyway plays a significant role in shaping the biodiversity of the local ecosystem attraction (Yeap et al., 2016; The Habitat Foundation, 2020). Amir (2019) noted that the mangroves and mudflats of Penaga and Kuala Muda have significant roles in preserving the coastline and local communities, especially from the winds and waves impact from the Malacca Straits.

The site of this case study, Kampung Kuala Muda in Penaga subdistrict, is a traditional fishing village located at the southern bank of the Muda River. Traditional fishing villages refer to the existence of the settlements due to the influence of the geography of the coastal area (Hassan, 2001). Kampung Kuala Muda can be classified as a low-rise, high-density traditional village with fishery as the main socio-economic activity (Hassan, 2004). The village exhibits an inland water village type where the planning pattern is developed towards the inland as the available strategic areas near the riverbanks have been occupied early (Hassan, 2001). Included in many river systems along the Western Coastal region, the Muda River separates two traditional fishing settlements and borders Penang and Kedah. Kampung Kuala Muda, Penang, consisting of Malay and Chinese residents, developed opposite Kota Kuala Muda, Kedah. The influence of Malay and Chinese architecture can be observed in the design of the dwellings, including the façade ornaments.

According to Shuib and Hashim (2018), the rural areas which feature the rural heritage and cultural landscape are being threatened due to the development, urbanization, and 
agricultural modernization, leading to the need to preserve the rural areas from the transformation.

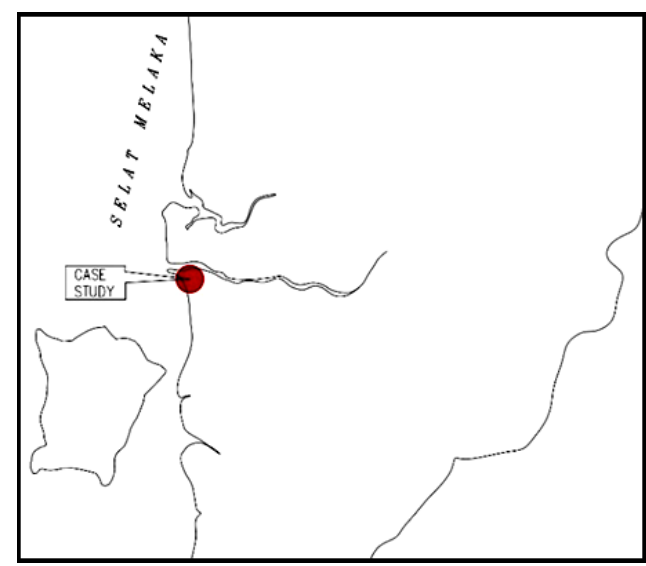

Figure 1. Key Plan

\subsection{Pathways, Edges and Nodes}

1.2.1 Pathways: Lynch (1960) stated that paths are considered predominant elements mentally mapped by many observers. Concurrently, paths allow the users to move regularly, infrequently, or potentially while connecting people from one destination to another and commonly fitting into a more extensive network (En et al., 2019; Lau et al., 2021).

1.2.2 Edges: Edges are noted as linear elements serving as continuity breaks and organizing features of a city. As edges border between two boundaries, they may act as barriers or seams between the two regions (Shamsuddin, 1997).

1.2.3 Nodes: Nodes, related to paths, are strategically located points in a city which may be the open or partially closed area that can be entered by the observers (Lynch, 1960; En, 2019). Additionally, nodes that include a hangout space or a covered plaza may also be portrayed in users' images as concentration points that gain importance due to their usage or physical character (Lynch, 1960; Alimin, 2020).

\section{METHODOLOGY}

The study has conducted a qualitative method to analyze the users' mental mapping of the urban design elements of Kampung Kuala Muda, namely the paths, edges, and nodes (Dant, 2019). Based on information from the local authority, Majlis Bandaraya Seberang Perai, a figure-ground urban layout plan is drawn using AutoCAD to understand the site's layout and the data comparison towards the quality of the urban design elements (En, 2019; Lau et al., 2021). In addition, a background research study and a site visit to Kampung Kuala Muda have been carried out to collect more information on the users' navigation throughout the site. Besides, informal interviews have been conducted with the users comprising of the locals.

\subsection{Pathways}

As one of the urban design elements of the case study studied in this paper, the path is measured according to the lengths and widths of the path, in meter, and the distance traveled to reach the path via the previous connecting path also in meter. The number of paths connected from the particular paths suggests the road's popularity and importance on the site. The permeability level of the paths from the main entrance is carried out using a justified graph to understand further the site's spatial arrangement (Ostwald, 2011; Silavi et al., 20117). The paths are mapped in hierarchical order from the main entrance to the arterial roads, leading to the collector roads and local roads. The focus is given to the paths taken by motor vehicles. The hierarchical order of the path is identified using the dominance of the path in terms of users' connectivity to the destination.

\subsection{Edges}

Edges are categorized under several divisions bordering the site of the case study. The edges of the site are measured using the length of the site edge covered in meters, and the significance of the edges to the local cultural fishing activity are considered to study the hierarchical order and the ratio for data comparison.

\subsection{Nodes}

Their socio-activity and popularity categorize nodes in Kampung Kuala Muda. The measurable factor of the nodes is determined using the area, in $\mathrm{m}^{2}$, and the distance traveled from the entrance(s), in meters, to reach the particular node. The ratio of the nodes is determined using the area.

\section{RESULTS}

\subsection{Pathways}

Referring to both Figure 2 and 3, the path pattern of the justified graph gives the idea of a single main entrance into the site, and the roads branch out from the primary access. Thus, the path pattern suggests a clear direction of the hierarchy of the road throughout the site. The main entrance is located at A1, Jalan Kuala Muda (also known as Kuala Muda Road), the main arterial road into the site. The main entrance further branches out to other second arterial roads, collector roads, and local roads. The permeability level of the paths in Kampung Kuala Muda reaches depth level 5.

Concerning nodes and edges of the site, the location of the Kuala Muda Beach edge is along the S2. Meanwhile, the edges Muda River and mangrove forest are both located along the S3. On the other hand, one of the primary fishing nodes is also along the S3, strategically situated between L10 and L11. The other primary commercial node is located between A1, S1, S2, C2, and L6. The nodes and edges of Kampung Kuala Muda are easily accessed via the arterial roads, thus allowing the users to navigate the village easily. The clear pathway from the main arterial road of Jalan Kuala Muda directs the users straight away to each of the nodes and edges.

The path pattern of Kampung Kuala Muda is straightforward, with a low depth permeability level. The local roads, mostly ending as cul-de-sacs, serving most residential increases privacy and security. However, the area can be easily accessed via the arterial and secondary arterial roads due to the low depth permeability level. Thus, the path pattern can be considered public due to the lower depth level of the justified graph. The egress of the site is either via the main arterial road A1, Jalan Kuala Muda, or the north unnamed secondary arterial road, S3. The site can also be exited via the river route, R1.

Based on observation and the site visit, there are three entrances into the village. The main entrance is through Jalan Kuala Muda, followed by the Muda River via boats. At the same time, 
the third one is a long and narrow road that accesses the neighboring village, Kampung Bakau Tua. Eventually, it links back to Jalan Kuala Muda, Penaga. Considering the level of activity and connectivity of the main entrances, the paths of
Kampung Kuala Muda can therefore be arranged in the hierarchical order of Jalan Kuala Muda (A1), followed by the Muda River (R1) and secondary arterial road S3.

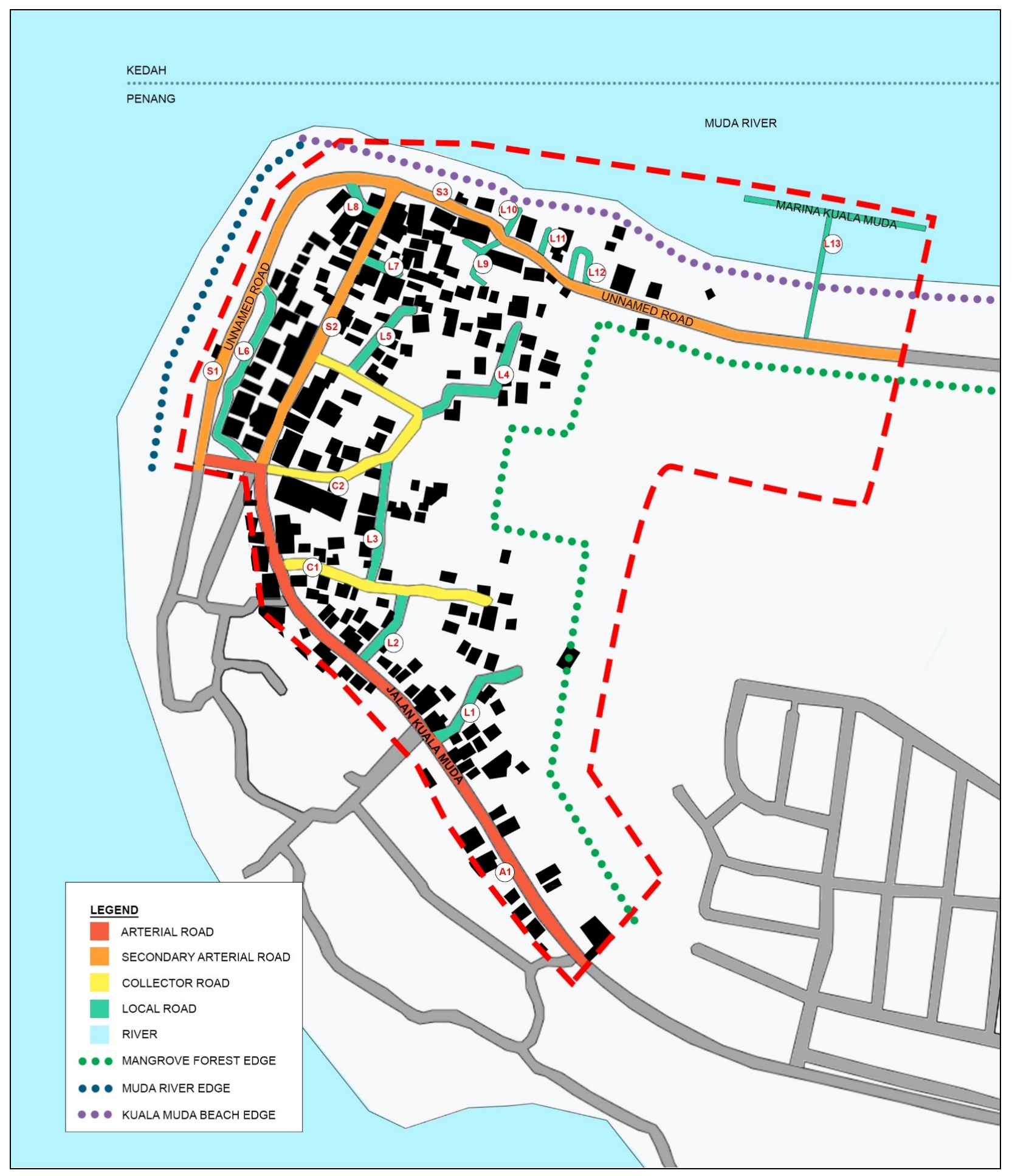

Figure 2. Paths and edges in Kuala Muda, Penang 


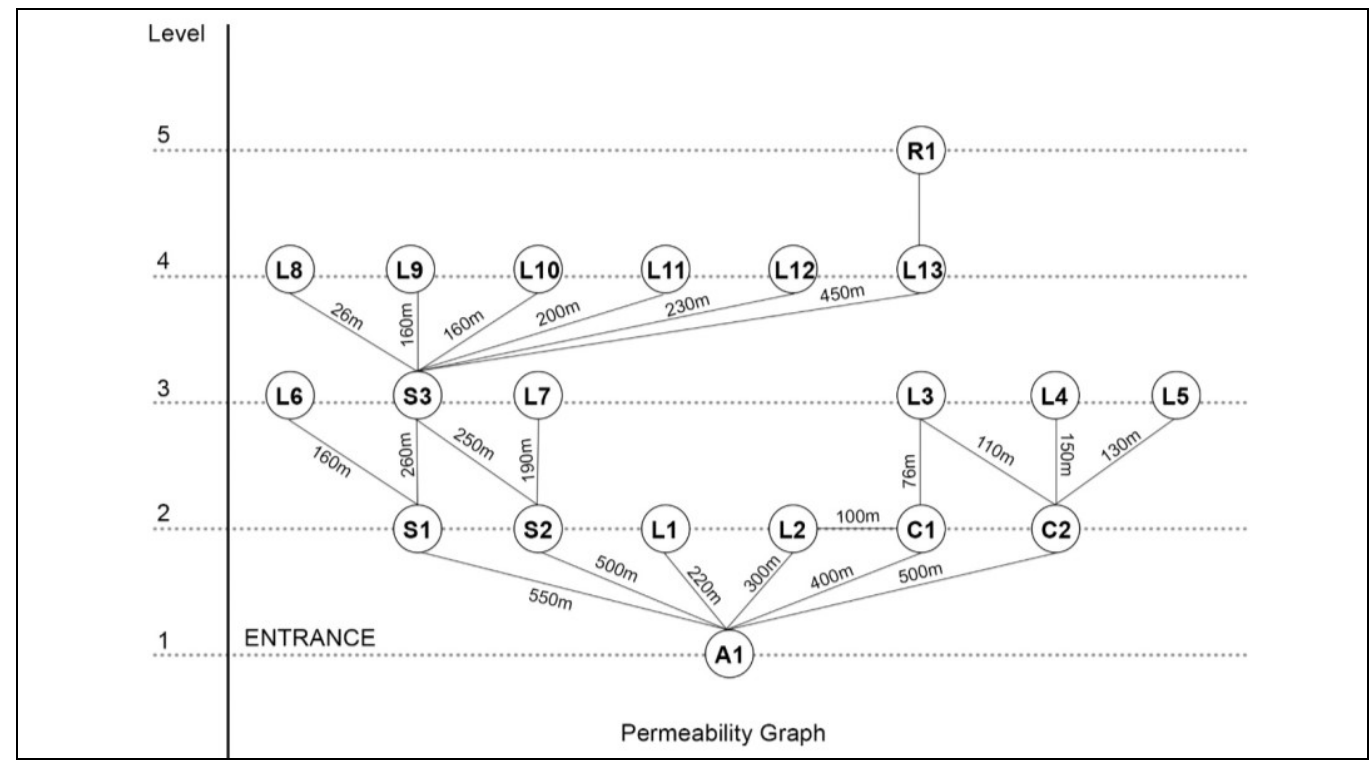

Figure 3. Justified Graph of Permeability Level

The path pattern of Kampung Kuala Muda is straightforward, with a low depth permeability level. The local roads, mostly ending as cul-de-sacs, serving most residential increases privacy and security. However, the area can be easily accessed via the arterial and secondary arterial roads due to the low depth permeability level. Thus, the path pattern can be considered public due to the lower depth level of the justified graph. The egress of the site is either via the main arterial road A1, Jalan Kuala Muda, or the north unnamed secondary arterial road, S3. The site can also be exited via the river route, $\mathrm{R} 1$.

Based on observation and the site visit, there are three entrances into the village. The main entrance is through Jalan Kuala Muda, followed by the Muda River via boats. At the same time, the third one is a long and narrow road that accesses the neighboring village, Kampung Bakau Tua. Eventually, it links back to Jalan Kuala Muda at Penaga sub-district. Considering the level of activity and connectivity of the main entrances, the paths of Kampung Kuala Muda can therefore be arranged in the hierarchical order of Jalan Kuala Muda (A1), followed by the Muda River (R1) and secondary arterial road S3. Thus, pathways are divided into arterial roads, collector roads, local roads, and rivers. Table 1 shows details about the roads' and rivers' composition. The most important path in Kampung Kuala Muda is the main arterial road, Jalan Kuala Muda (A1), which diverges into more minor roads. Most of the urban elements in the site can be accessed via this road.

\begin{tabular}{|l|c|c|c|}
\hline \multicolumn{1}{|c|}{ Road Types } & Denotation & $\begin{array}{c}\text { Length } \\
\mathbf{( m )}\end{array}$ & $\begin{array}{c}\text { Percentage } \\
\mathbf{( \% )}\end{array}$ \\
\hline Arterial Road & $\begin{array}{c}\text { A1 } \\
\text { (Jalan Kuala } \\
\text { Muda) }\end{array}$ & 500 & 15 \\
\hline \multirow{2}{*}{$\begin{array}{l}\text { Secondary } \\
\text { Arterial Roads }\end{array}$} & S1 & 240 & 7.15 \\
\cline { 2 - 4 } & S2 & 250 & 7.45 \\
\cline { 2 - 4 } Collector Roads & S3 & 500 & 15 \\
\cline { 2 - 4 } & C2 & 250 & 7.45 \\
\hline \multirow{3}{*}{ Local Roads } & L1 & 100 & 3.00 \\
\cline { 2 - 4 } & L2 & 60 & 1.79 \\
\cline { 2 - 4 } & L3 & 110 & 3.28 \\
\hline
\end{tabular}

\begin{tabular}{|c|c|c|c|}
\hline \multirow{7}{*}{} & L4 & 120 & 3.60 \\
\cline { 2 - 4 } & L5 & 70 & 2.09 \\
\cline { 2 - 4 } & L6 & 140 & 4.17 \\
\cline { 2 - 4 } & L7 & 30 & 0.89 \\
\cline { 2 - 4 } & L8 & 40 & 1.19 \\
\cline { 2 - 4 } & L9 & 55 & 1.64 \\
\cline { 2 - 4 } & L10 & 25 & 0.75 \\
\cline { 2 - 4 } & L11 & 25 & 0.75 \\
\cline { 2 - 4 } & L12 & 60 & 1.79 \\
\cline { 2 - 4 } & L13 & 110 & 3.28 \\
\hline River & R1 & 500 & 15 \\
\hline
\end{tabular}

Table 1. Path data comparison

1.1.1 Arterial Roads: There are three arterial roads with Jalan Kuala Muda, A1, the main arterial road, followed by S1 and S2 at depth level 1, and S3 at depth level 3.

3.1.1 Collector Roads: Two collector roads can be hierarchically arranged with $\mathrm{C} 2$ followed by $\mathrm{C} 1$ at depth level 2 .

3.1.2 Local Roads: 13 local roads with L1 and L2 are more easily accessible with depth level 2, 5 in-depth level 3, and the remaining six in-depth level 4.

3.1.3 River: Another important water pathway is the Muda River (R1). The river is associated with the local fisheries activities and hugely contributes to the local economy of the villagers. There are also boat services at the river crossing.

\subsection{Edges}

Based on the observation, there are three types of nature edges (Figure 2 and Table 2): Kampung Kuala Muda, Muda River at the north area of the site, and Kuala Muda Beach at the west region. At the same time, there is a mangrove forest in the east part of the fishing village. The most crucial edge for this village is the Muda River. The river borders between two states, Penang and Kedah. There are also significant fishing activities taking part at this river, and it can be observed that most of the boats of the fisherman are parked at this side of the fishing village. The jetty for the fishermen to load their catch is situated 
before being sold at the Whispering Market. The water currents of the river are low, and waves of the beach can be avoided.

Besides that, Kuala Muda Beach is also an important edge in the fishing village as it borders the village and the beach. Another important edge is the mangrove forest. It is because the forest marks the separation between Kampung Kuala Muda and the neighboring village, Kampung Bakau Tua. Therefore, the importance of the edges for the cultural activity of the case study can be hierarchically identified as Muda River, Kuala Muda Beach, and the mangrove forest.

\begin{tabular}{|l|c|c|}
\hline \multicolumn{1}{|c|}{ Edges } & $\begin{array}{c}\text { Length of site } \\
\text { edge covered }(\mathbf{m})\end{array}$ & $\begin{array}{c}\text { Percentage } \\
(\mathbf{\%})\end{array}$ \\
\hline Muda River & 530 & 33 \\
\hline Kuala Muda Beach & 300 & 18 \\
\hline Mangrove forest & 800 & 49 \\
\hline
\end{tabular}

\subsection{Nodes}

Table 2. Edge data comparison

Several nodes (Figure $4 \&$ Table 3 ) are identified in the village: commercial, fishing activity, and religious nodes. The most important node in the village is the commercial node, mainly the market area. The fishing village is known for the Whispering Market Kuala Muda, located next to the Pasar Nelayan Kuala Muda area and near the only jetty in the village, Marina Kuala Muda. The market connects the local fishermen with the visitors of the village. Most of the fisheries activities take place in this area. Around the market, there is also Lembaga Kemajuan Ikan Malaysia (LKIM) Fish Declaration Centre and other commercial activities such as the eateries.

According to the informal interview with one of the hawkers, the Whispering Market is also open during this Covid-19 pandemic but without the infamous whispering culture before the transactions between the sellers and buyers. Besides, some stalls open in the evening near the Kuala Muda beach area, which serves the locals and visitors of the beach. The religious nodes are also significant in this village. With the community mainly consisting of Muslims, both Masjid Jamek Al-Hidayah and Masjid Haji Othman located within Kampung Kuala Muda become important nodes that bring the local community together as various religious activities take place here. Though Masjid Jamek Al-Hidayah is observed to be more significant due to the large area, height, and location of the mosque.

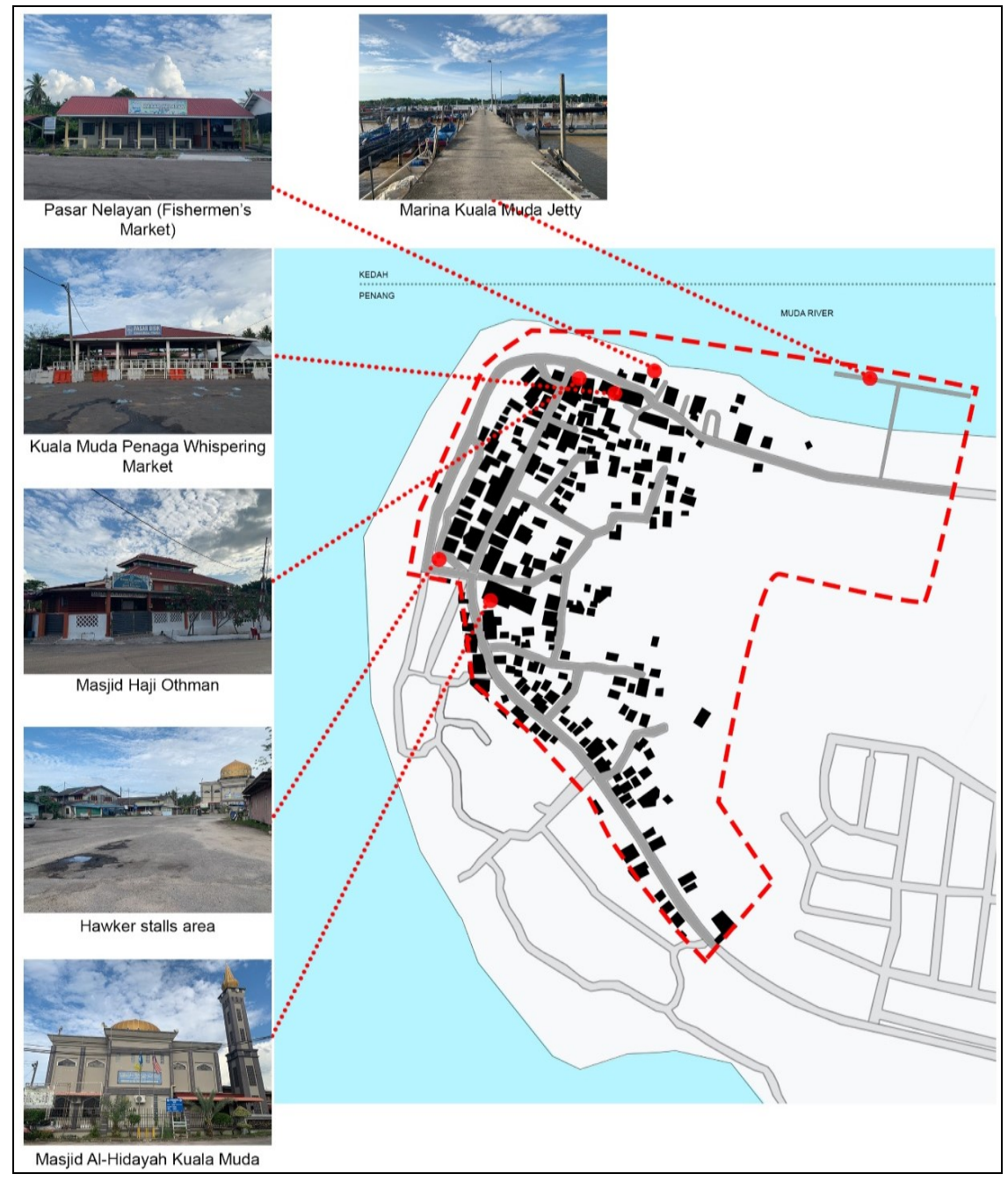

Figure 4. Edges

\begin{tabular}{|c|c|c|c|c|c|}
\hline Nodes & Node Types & Level & Area (m2) & Percentage (\%) & Level of Socio-Activity \\
\hline Whispering Market & Commercial & Primary & 1030 & 16 & Very Good \\
\hline
\end{tabular}




\begin{tabular}{|l|c|c|c|c|c|}
\hline Pasar Nelayan (Fishermen's Market) & Commercial & Primary & 700 & 11 & Good \\
\hline Food stalls & Commercial & Secondary & 745 & 11 & Good \\
\hline Hawker Stalls & Commercial & Secondary & 340 & 5 & Good \\
\hline Jetty Marina Kuala Muda & Fishing & Primary & 1450 & 22 & Very Good \\
\hline Riverfront & Fishing & Primary & 800 & 12 & Good \\
\hline Masjid Jamek Al Hidayah Kuala Muda & Religious & Primary & 1245 & 19 & Good \\
\hline Masjid Haji Othman & Religious & Secondary & 235 & 4 & Good \\
\hline
\end{tabular}

Table 3. Node data comparison

\section{DISCUSSION}

\subsection{Paths}

The paths of Kuala Muda Fishing Village are straightforward and clear to guide the visual perception in the village. The most important Jalan Kuala Muda direct the users into the other more minor roads and the nodes of the site, including the jetty and the commercial area. This road provides a clear directory to the users for their movement around the site. The weakest main path is the unnamed road that can be accessed via Jalan Kuala Muda. Although it directs the users to some important nodes at the beginning of the path, the long and narrow path is followed by no attractions at both sides of the road and is lined with mangrove forest. Moreover, there is no boundary or clear guidance to the connection that the road may lead to.

\subsection{Edges}

The site's edges are considered most dominant to the users of all the three urban elements studied in this analysis. Therefore, the site is perceived as having satisfactory edge elements to the users. The most dominant edge perceived by the users is the Muda River that marks the end of the residential area of the site and the beginning of the fishing activities, which is restricted by the parked fishermen's boats and the existence of the Marina Kuala Muda Jetty. On the other hand, the weakest edge element of the site is the mangrove forest, while the Muda River is considered the best edge. It is contributed by the fact that the site is located at the border of Penang and Kedah and is the borderline for the users to get into or disembark from the water transportations. On the other hand, the mangrove forest does not portray a clear borderline between Kuala Muda Village and the neighboring residential areas, Taman Desa Kuala Muda (translated into Desa Kuala Muda Garden City) and Bakau Tua Village.

\subsection{Nodes}

The nodes of the village are perceived as a medium compared to other urban elements. The best node in the study area is the commercial nodes featuring the markets where most fisheries activities occur. Owning to its name, Kuala Muda Fishing Village is well known for its fresh seafood that is loaded daily. It contributes to the success of the commercial node as visitors frequent the markets to buy the seafood at a much lower price. Besides, the commercial node is conveniently accessible from the Jalan Kuala Muda and subsequent secondary arterial road, although situated at the village's inner part.

\section{CONCLUSION}

Based on the study, the urban elements of Kuala Muda Fishing Village, consisting of paths, edges, and nodes, have been identified. The nature of the fishing village can be observed clearly in this case study in terms of the planning and the location of the site's cultural activities. Based on the analysis of the study, the most dominant urban design element of Kampung Kuala Muda is the edges. The edges create a separation of a river, mangrove swamp, Kuala Muda settlement, and coastal area while allowing a seamless connection through the fishing activities. Therefore, the edges contribute largely to the planning of Kampung Kuala Muda as a fishing village.

On the other hand, the nodes are perceived as the weakest elements of the site, although being significant in the contribution of the local community. The location of the nodes, which are mixed throughout the village, suggests more detailed guidance for the users to navigate in the village. However, the urban design elements of Kampung Kuala Muda work efficiently together in delivering the significance of the site, especially for what it is well-known for, the local culture of fishing, and the intangible heritage of the whispering auction. However, the site visit is carried out during the pandemic of Covid-19, which limits the observation of the quality of the urban elements as perceived by the users in the village. A further research study can be carried out on the effects of the current pandemic on the users' perception of the urban elements in the village.

\section{ACKNOWLEDGEMENTS}

The study is under financial support from a Bridging Grant (304.PPBGN.6316521), Universiti Sains Malaysia.

\section{REFERENCES}

Alimin, M. A. Y. B., Chan, L. H., Hassan, A.S., Arab, Y., Witchayangkoon, B. \& Syahbana, J. A. (2021). Spatial Arrangement Analysis of Kampung Bintawa Hilir in Sarawak. International Transaction Journal of Engineering, Management, \& Applied Sciences \& Technologies. 12(2), 12A2K, 1-15.

Amir, A.A. (2019). Learn from Our Past. New Straits Times. Retrieved 15 May 2021 from https://www.nst.com.my/opinion/ columnists/2019/12/551085/learn-our-past

Daut, B.M., Hassan, A.S., Abdul Nasir, M.H. \& Witchayangkoon, B. (2019). Analysis of Mental Mapping in Urban Design for the Case of Kampung Teluk Kecil, Pangkor Island. International Transaction Journal of Engineering, Management, \& Applied Sciences \& Technologies. 11(13), 11A13I, 1-10.

En, T.Y., Aripin, D., Hassan, A.S., Abdul Nasir, M.H. \& Witchayangkoon, B. (2019). Analysis of Urban Design Elements with a Case Study at Heritage Buildings and Fisherman Villages, George Town, Penang. International Transaction Journal of Engineering, Management, \& Applied Sciences \& Technologies. 10(19), 10A19J, 1-17. 
Hassan, A.S. (2001). Corak Perumahan Tradisional Berkepadatan Tinggi: Perkampungan di Sepanjang Pantai Barat Semenanjung Malaysia. Penang: Universiti Sains Malaysia Press.

Hassan, A.S. (2004). Sustainable Future Urban Patterns and Socio-Economic Activities of Tropical Wetlands in Southeast Asia. Encyclopedia of Life Support Systems. Oxford: EOLSS Publishers. 2, 293-299.

Lau, Z.Y., Tan, X.Y., Arab, Y., Hassan, A.S., Dumrongchai, P., \& Rakhmatulloh, A.R. (2021). A Study on Kevin Lynch's Urban Design Elements with a Case Study at Taman Seri Juru in Simpang Ampat Town of Penang. International Transaction Journal of Engineering, Management, \& Applied Sciences \& Technologies. 12(6), 12A6A, 1-13.

Lynch, K. (1960). The Image of the City. Cambridge: The MIT Press.

Mas'ad, A. M. (2018). Shariah Analysis on the Concept and Application of Whispering Auction Sales: A Case Study of Pasar Bisik Kuala Muda Kedah. The Malaysian Journal of Islamic Sciences. 24, 55-68.

Ostwald, M.J. (2011). A Justified Plan Graph Analysis of the Early Houses (1975-1982) of Glenn Murcutt. Nexus Network Journal. 13(3), 737-762.

The Habitat Foundation (2020). Conserving the Migratory Shorebirds and Wetlands of Teluk Air Tawar-Kuala Muda Coast. Retrieved 25 April 2020 from https://habitatfoundation. org.my/ 2020/02/24/conserving-the-migratory-shorebirds-andwetlands-of-teluk-air-tawar-kuala-muda-coast/

Rahmathulah, K. (2016). Pasar Bisik Kuala Muda Jadi Tarikan. Berita Harian Online. Retrived 25 April 2021 from https://www.bharian.com.my/bhplusold/2016/02/124875/pasarbisik-kuala- muda-jadi-tarikan

Shamsuddin, S. (1997). Identity of place: A Case Study of Kuantan Town Centre, Malaysia. Unpublished Ph.D. Thesis. The University of Nottingham, Retrieved 12 May 2021 from http://eprints.nottingham.ac.uk/12120/1/243706.pdf

Shuib, K.B., Hashim, H. (2018). Heritage Value of the Traditional Malay Villages as Protected Landscapes. Lestari: Citra Peradaban Melayu. Merbok: Perpustakaan Sultan Badlishah Press. 66-88.

Silavi, T., Hakimpur, F., Claramunt, C. \& Nourian, F. (2017). The Legibility and Permeability of Cities: Examining the Role of Spatial Data and Metrics. ISPRS International Journal o Geo-Information. 6(4), 101, 1-20.

Fong, S.Y., Yeap, C.A., \& Butt, C. (2016). A Pilot Rapid Assessment of Selected Ecosystem Services Provided by the Teluk Air Tawar-Kuala Muda Coast IBA in Pulau Pinang. Kuala Lumpur: Malaysian Nature Society (MNS Conservation Publication No. 16). 